\title{
Beyond Tweets: Pragmatic Analysis of Humor as a Brand Image in Burger King's Tweets
}

\author{
Amadhea Naidriya Putri \& Marti Fauziah Ariastuti \\ English Study Program, Faculty of Humanities \\ Universitas Indonesia. \\ Kampus UI Depok, Jln. Margonda Raya, Depok, Jawa Barat - 16424 \\ E-mail: marti.fauziah@ui.ac.id
}

Volume 6 Nomor 1

April 2019: 12-23

\begin{abstract}
ABSTRAK
Melebihi Tweet: Analisis Pragmatis Humor sebagai Citra Merek di Tweet Burger King. Salah satu bentuk strategi komunikasi yang paling populer adalah humor. Meskipun berbagai penelitian telah dilakukan untuk meneliti hubungan humor dan semantik dalam konteks iklan, relatif sedikit yang telah membahas hubungan antara tweet humor, komunikasi bisnis, dan pragmatik. Oleh karena itu, tujuan utama dari penelitian ini adalah untuk (1) menyelidiki konstruksi tweet humor berdasarkan delapan sumber daya pengetahuan dan (2) membahas fungsi pragmatisnya. Penelitian ini menggunakan versi ekstensi dari Teori Umum Humor Verbal Attardo (Tsakona, 2013), dilengkapi dengan analisis fungsional teks Brinker. Dipilih berdasarkan style humor yang digunakan (Martin, 2003), data untuk penelitian ini terdiri dari 111 tweet humor dari akun Twitter Burger King antara tahun 2016 dan 2018. Tiga tahun dipilih karena tampaknya ada korelasi positif antara penggunaan strategi humor di media sosial dan kinerja penjualan Burger King selama tahun-tahun itu. Temuan utama adalah bahwa Burger King: (1) menerapkan konstruksi humor yang berbeda di akun Twitter Burger King, terutama dalam oposisi teks, mekanisme bahasa, target, dan konteks; dan (2) menggunakan fungsi tweet humor yang berbeda untuk mempersonalisasi merek (2016), meminta pelanggan untuk melakukan beberapa tindakan (2017), dan mempromosikan produk (2018).
\end{abstract}

Kata kunci: Burger King; tweet humor; Teori Umum Humor Verbal; pragmatis; analisa fungsi teks

\begin{abstract}
One of the most popular forms of communication strategy is humor. Although various studies have accounted the relation of humor and semantics in advertisement context, relatively little has discussed the link between humor tweets, business communication, and pragmatics. Therefore, the main aim of this study is to (1) investigate the construction of humor tweets based on eight knowledge resources and (2) discuss its pragmatic function. The study applies the extension version of Attardo's General Theory of Verbal Humor (Tsakona, 2013), complemented with Brinker's text functional analysis. Selected based on style humor used (Martin, 2003), the data for the study consist of 111 humor tweets from Burger King Twitter account between the year 2016 and 2018. The three years are selected because there seems to be a positive correlation between the use of humor strategy in social media and Burger King's sales performance during those years. A key finding is that Burger King: (1) applies different construction of humor in Burger King's Twitter account, especially in Script Opposition, Language Mechanism, Target, and Context; and (2) uses different function of the humor tweets for personalizing the brand (2016), asking the customer to do some act (2017), and promoting the products (2018).
\end{abstract}

Keywords: Burger King; humor tweets; GTVH; pragmatics; text functional analysis 


\section{Introduction}

"I am a brand, seeking for retweets and attention," Humorous tweet posted on Twitter by MoonPie, a brand account, in 2017

In recent years, the popularity of Twitter has opened a new pattern of brand communication with the audience. This massive micro-blogging facilitates brands to freely share or receive a short message up to 140 characters called tweets. Twitter also allows the brands or the audience to follow, likes, retweets, or simply read the tweets they find interesting. Looking at how one tweet can be easily transmitted to the audience, brands strive to take advantage of Twitter. Brands are becoming more active and are trying to adjust to the new methods of business engagement in Twitter. As might be expected, how the brand uses Twitter is as essential as building brand equity. Some brands are likely to generate conversation or voice their products with humor. Their quick-witted and humorous content are expected to capture people's attention, allowing the brand to stand out positively or negatively, in heated competition. However, producing and curating a meaningful humor to fit in the short text format of Twitter is challenging. Besides, humor tweets might as well express the indirect message that needs to be decoded by the audience. In this case, the audience cannot just rely upon the literal meaning but pragmatic meanings to avoid miscommunication. Linguistically speaking, pragmatic interpretations is suitable for analyzing the humor production and comprehension in communication (Hoicka, 2014).

Various studies have started to address the importance of humorous content used in Twitter (Alaman \& Rueda, 2011) to communicate different purposes (Yliopisto, 2016), notably in business and political context twitter (Oyebode \& Adegoju, 2015; Farias, 2017; Lalancette \& Raynauld, 2017). Their studies show a clear intersection between tweets, hashtag, and intended messaging. It turns out that Twitter and its humorous content can facilitate the politician, public figure, brand or a person in general to establish their image and disseminate ideas or values into diverse audience.
Other recent studies explore on how humor tweets like mocking, satire, and parody often possess indirect messages that reinforce either negative or positive impression to the audience (Davis, Love, \& Killen, 2018). While these studies about humor tweets and its intended meaning have been conducted, many gaps still remain. There has only been little attention to research that explores how humor tweets, particularly by brand, works to make meaning, communicate with the audience, and build an image. In addition, although studies of humor tweets are growing fast, studies investigating the relationship between humor tweets and brand image within pragmatic lens or General Theory of Verbal Framework (GTVH) are still limited, and no study has been reported on analyzing how Burger King's humor tweets work to shape brand image with pragmatics; meanwhile, fast food brands use of humor in Twitter have grown significantly.

From early 2016, Burger King has attracted more than millions of followers and become one of the most active fast food twitter accounts. In fact, their humorous tweets often become trending topic on Twitter for days. In addition, compared to the other fast food accounts that use humor, like Wendys, Burger King has its own place in people. Burger King is able to penetrate general public interest on their humor, not only to the Americans. It can be said that Burger King's humor tweets is more common, personalized, and can be accepted by people outside America. Accordingly, researchers feel the need to examine these humor tweets to see how they work. That being the case, this study attempts to fill the gap as well as to contribute to the growing body of research in linguistic humor.

In this study, there are 111 tweets obtained containing humor from the year 2016 to 2018 . These data are analyzed to explore: (1) how the humor in Burger King's tweets is constructed; and (2) what pragmatics function of humor is enacted in Burger King's tweets. To answer these questions, this paper attempts to use the extended version of the General Theory of Verbal Humor by Attardo (2008) and Tsakona (2013). This model of the framework is based on eight types of knowledge resources: a script opposition (SO), a logical mechanism (LM), a situation (SI), a target (TA), 
a narrative strategy (NS), a language (LA), a metaknowledge resources (meta), and a context (CO). Another approach to determine and maximize the results of how the humor tweets are functioned, this paper uses Text Functional Analysis by Brinker (2005). The rest of paper is organized as follows: first, this paper introduces the related work, fundamental concept, and literature about twitter, humor, and pragmatics. The next section describes and explains the methods of data collection. The last section presents and discusses the results or findings of the study, before it finally arrives at the conclusion and offers suggestions for further research.

The purpose of this section is to introduce the theoretical concepts that play a big part in forming the analysis. There are two concepts that have been selected in relevance to the research questions.

\section{General Theory of Verbal Humor (GTVH)}

There are three major humor studies that have been highlighted over centuries: superiority (sociological) theory, relief (psychoanalytical) theory, and incongruity theory (Canestary and Bianchi, 2013). Emerging from these perspectives, scholars have developed several different approaches of humor theories and one of them is The General Theory of Verbal Humor (GTVH) by Attardo and Raskin in 1991. GTVH is proposed as the second generation of Raskin's (1985) Semantic-Script Theory of Humor (SSTH). Although both of them have been defined as the most significant linguistic humor theories (Brone et al., 2006), GTVH is known for its attempt for explaining humorous circumstances from interdisciplinary theories, as it is incorporated with not only semantic but also pragmatics theories (Attardo, 2013). The GTVH proposes the theory that allows people to account how humor works and its function, as well as to understand similarity and differences between jokes, via a set of six hierarchically parameters, called Knowledge Resources (henceforth KRs). Due to its lack of contextualization and interpretation of humor, Canestari (2010) presents the seventh KR, the Meta-Knowledge Resource (Meta KR), followed by Tsakona (2013) that expanded the analytical scope and tools of GTVH with the eighth $\mathrm{KR}$, the Sociocultural Context Resource (SC). The proposed eight expansion KRs of GTVH presented in this theory are:

1. Script Opposition (SO)

Raskin introduces the concept of Script Opposition (SO) in 1985 within the theory of SSTH. SO focuses on the incongruity, overlapping or "shadow oppositeness" of each joke (Attardo, 2013). He further states that many jokes use this kind of 'binary categories', which are $\mathrm{im} /$ possible, ab/normal (un/ expected), and non/actual.

2. Logical Mechanism (LM)

The LM in KRs is the resolution phase after the SO (Attardo and Hampelmann, 2002). LM has a function to justify the incongruity (Ziv, 1984) or embodies the logic mechanism of each joke (Attardo, 2013).

3. Situation (SI)

According to Attardo (2013), each humorous text must be telling "about something". This may refer to the activities, setting, or instrument that lay behind each joke.

4. Target (TA)

Defined as the 'butt' of the jokes, target identifies the individuals or groups that are being regulated within the stereotypes attached in the society (Attardo, 2013). Therefore, jokes that are not 'agressive' or ridicule something are considered not to have this parameter.

5. Narrative Strategy (NS)

This parameter attempts to identify the form of narrative organization in any jokes (Attardo, 2013), either simple narrative, dialogue, or a riddle (Masaeli \& Shahreza, 2016).

6. Language (LA)

Attardo (2013) states that LA is responsible for the verbalization of a humorous text. This emphasizes the wording, placement of sentences, the variation of language, and syntactic constructions.

7. Meta-Knowledge (Meta KR)

Meta-KR signifies "the signals that refer to the speaker's intention of being humorous" and the reaction from the audience (Canestrari, 
2010). Most importantly, meta-KR proposes an approach to see how one verbalizes their humor within such signals, which Canestrari (2010) refers to as verbal, non-verbal, and para-verbal.

8. Context $(\mathrm{CO})$

Based on Tsakona (2013), CO presents sociocultural presuppositions and metapragmatic stereotypes in the humor productions and interpretation. In other words, $\mathrm{CO}$ proposes the detailed information or context which evolves around the humor.

\section{Text Functional Analysis}

Following the previous theoretical concept, text functional analysis focuses more on the function of the text (Brinker, 2005 in Arhoj, 2011). Using pragmatics function and speech act, this approach is a valuable tool in determining the intention of the sender in business communication. At the same time, text functional analysis is able to determine the goal of the communication without having direct access to the source (Arhoj, 2011). Consequently, this concept can establish what the brand is trying to communicate with the humor tweets without having to ask directly to the brand. There are five functions, which are the informative function, the appellative function, the obligation function, the contact function, and the declarative function (Brinker, 2005 in Arhoj, 2011) that has correlation with Searle's illocutionary acts.

The first function is informative function. This is when a text simply contains information that the addresser intends to impart with the addressee. In terms of advertisement, the text may includes a list of characteristics of the products or services (Simon, 2008). Usually, the text is in a form of narrative or argument to appeal the customers. The appellative function is when a text contains an appeal. In this case, the addresser makes an appeal to the addressee to do something or to act in a certain way. The obligation function is when a text contains some commitments that the addresser has to fulfill. In advertisement, if the addresser breaks the promises, for example the advantages of products, the addressee can take legal actions (Simon, 2008). The fourth function is contact function. This text expresses the addresser's desire to have an intimate relationship or get in contact with the addressee. The last one is declarative function or a text that addresses certain fact of reality (Arhoj, 2011). According to Brinker (2005), declarative text has the same function to wills.

\section{Methods}

To analyze how the humor works in Burger King's tweets, this study uses the extended version of General Theory of Verbal Humor (GTVH) by Attardo (2001) \& Tsakona (2013) and the Text Functional Analysis (Brinker, 2005). These two approaches are within the interdisciplinary field of linguistics, distinguished by its focus on humor used in any communication, notably the advertisement context, and the methods used in the field of pragmatics. In addition, Attardo (2013) asserts that the GTVH is suitable not only for a longer humor text, but also a short one. That means GTVH can be used for short jokes found in tweets. As have been explained in the previous section, text functional analysis is essential as it subsequently allows the researcher to know the intention of the humor tweets without direct contact to the brand selected. This empirical study accumulates the data using library research and social media record from the brand's websites. The twitter account being referenced is visible for public. Therefore, the humor tweets can be easily gained from the online platform.

The analysis is performed by first categorizing each piece of data according to the kind of humor and its details, which include the number of times the tweets being retweeted or marked as favorite and the time it is being posted. To reduce the large volume of data set, using the four types of humor by Martin (2003), which is based on his Humor Styles Questionnaire, this study examines 111 humor tweets from Burger King's Twitter account within the period of 3 years $(2016,2017,2018)$. The reason for choosing those years is because according to Statista, the revenue of Burger King increased from 1.14 billion U.S dollars in 2016 to 1.22 billion U.S dollars in 2017 , showing the effectiveness of humor advertisement strategy for 
new products worldwide. Meanwhile, the statistics of the 2018 revenue has not been released when this study is conducted. Next, the data set is tabulated and analysed by means of the theoretical framework. Finally, humor tweets that receive the most attention are further examined. This involves descriptive, qualitative, and quantitative analysis throughout the examination of particular tweets.

\section{Results and Discussions}

Twitter marketing is all about numbers, i.e the number of retweets, loves, or replies from anyone on Twitter. The more people repost the tweet or show interest by pushing the love button, the more it helps the brand to reach their marketing or business engagement goals. According to the data, in the case of Burger King, the top humor tweets during 2016, 2017, 2018 are about celebrity or idols, competitors, and annual celebration day respectively. One humor tweet referring to he song "Euphoria" by K-Pop group idol (BTS) reaches more than 19.000 retweets and 38.000 likes. It can be said that collaborating an artist is a smart move by Burger King. For example, the 2016 tweet that made fun of Liam Payne and associated him with Whopper gained more than 3000 retweets and 4300 likes. This is relevant with the theory of Fan Economy, which states that fans are the consumer as well as an active audience in the mass media that carry tight bonds to the artist. This means when fans find the thing, for instance, tweets that are associated with their artist, they become the real activists (Liang \& Shen, 2017). They participate with the tweets and share it to the fandom or public with the aim of supporting their idols and promoting the brand in return. Other tweets that gain attention from the public are tweets about competitors. Instead of shading each other in a negative way, in 2018, Burger King asked Wendy to go prom, and it gained more than 37.000 likes and 5600 retweets. This shows that personification jokes are still relatable and funny to the audience. Other than that, April Fool's joke by Burger King had a good drive performance likes and eventually brought the public's attention with 2500 retweets and 6100 likes. More specifically, Burger King was trying to get people to believe they sell a chocolate whopper, which is unusual and utterly outrageous. It appears that people still accept and embrace the practice of the most light-hearted day of the year. On the side note, the results suggest that we are able to discern the pattern of Burger King's humorous tweets for over three years.

Ultimately, the primary goals of this paper are to understand the construction of humor and its function in advertisement context, by first investigating and differentiating the humor tweets. Nine categories are examined and identified with corresponding subcategories. In Burger King tweets, starting with Knowledge Resources (KRs), eight out of nine categories are identified: SO, LM, SI, NS, TA, LA, Meta, CO. The GTVH approach allows the analysis to perceive the process of constructing humor tweets in Burger King. It is found that there is significant differences in the construction of humor tweets each year. This finding validates the notion that humor in Burger King's tweets are consistently maintained in different style, situation, logics, and contexts, by the public relation team as a part of their strategy in social media engagement.

Figures 1-9 present the analysis of each Knowledge Resources (KRs) and text functional that are included in the humor tweets of Burger King. Based on the comparative data analysis, it is known that Burger King has more humor tweets in 2017 compared to 2016 and 2018 with a total of 55 tweets. However, it is found that the types of humor tweets differ from year to year.

\section{Knowledge Resources (KRs)}

Empirically, SO (Script Opposition) is the most abstract, yet has the highest level of hierarchy in all KRs (Attardo, 2001). The script in here means that the humor carries information about something and has its oppositeness relation, depending on the culture, time, and place of the production (Attardo, 2013). Acoording to Hempelmann and Ruch (2005), SO involves major theme such as possible/impossible, normal/abnormal, and actual/ non-actual.

Figure 1 represents the number of script opposition used by Burger King in three different 
years. Interestingly enough, approximately half of humor tweets in 2016, 2017, 2018 uses different script oppositions, i.e. actual/non-actual (53\%), normal/abnormal (58\%), possible/impossible (61\%) respectively. If it is accumulated from 3 years, it is revealed that Burger King prefers to make fun of something that is not normal or impossible to happen. Consider the following examples of the most frequent script opposition shown below: a. Actual vs. Non-actual (2016)

"No Reese's Pie until you finish your homework. Just kidding, we don't care"

This humor tweet carries information about the rule that should be followed by someone. The rule is to not eat Reese's pie before completed the task, while the opposites of it is having the pie. A joke about eating a pie can be considered something that is real, which may exist in reality. Finishing homework is also a common activity or event that can occur at any time in human life.

b. Normal vs. Abnormal (2017)

"Girlfriend: I wonder if he's thinking about another woman;

Boyfriend : how many onion rings does it take to fill a bathtub"

In this joke, the boyfriend is assumed to think about another woman. In fact, he is thinking about onion rings. However, it is abnormal to consider that a man is thinking about and measuring the bathtub just to fill it up with onion rings. In addition, the relationship only occurs to human or living things. Onion rings are a food and do not have a feeling. Again, if a man regards her woman as an onion rings,

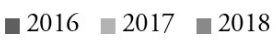

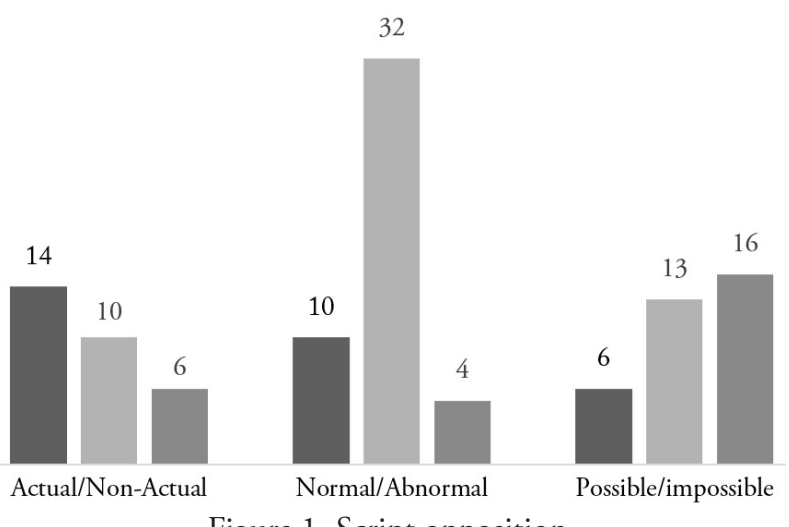

Figure 1. Script opposition. it can be concluded that there is something abnormal going on with him.

c. Possible vs. Impossible (2018)

"Do you ever wonder if salt and pepper are real friends or just work friends?"

Here in this joke, salt and pepper are assumed to have a relationship like human do. Salt and pepper are not even a creature like an animal, but they are being questioned as if they are a bunch of individuals who meet often outside of their workplace. In fact, making jokes about a friend can be defined as human traits. Hence, although salt and pepper are considered a fine pair of condiments, it is impossible for them to be alive and making friends.

Taking up humorous tweets need the justification of the incongruity and faulty (Freud, 1905 in Attardo and Hampelman (2002), means that most joke may have logic faulty and correct reasoning. A further point to note is that Logical Mechanism (LM) is optional (Masaeli \& Shahreza, 2016). However, this paper tries to classify all tweets into several different forms of LMs that have been developed by Attardo, Hempelmann, and Maio (2002).

Figure 2 shows that $33 \%$ of total tweets leans toward any kind exaggeration humor. However, in 2017 Burger King often used analogy in their humor tweets. In terms of other LMs, there are 5 humor tweets in 2016 that ignores the obvious truth. The following explanations demonstrate the example of the most used logical mechanism in Burger King's tweets:

$\square 2016 \square 2017 \square 2018$
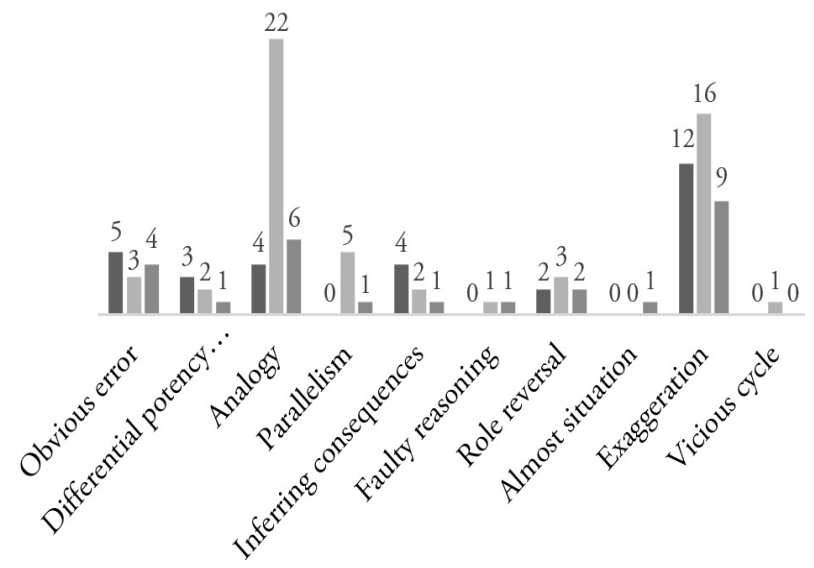

Figure 2. Logical mechanism. 
a. Exaggeration (2016 and 2018)

This LM is used in high number in both years. 53\% of tweets in 2016 and 34\% in 2018 are exaggeration jokes. A good example that can illustrate this is:

"Mean people would be so much cooler if they were Chicken Fries"

An exaggeration means projecting something by exaggerating its element or characteristics (Paolillo, 1999). Oxford Dictionaries also define exaggeration as a statement for making something seem better or worse than the actual situation. The script is generally directed at people who eat chicken fries, presumably, Burger King's chicken fries would be better. However, they exaggerate the personality of people, more than just "cool". Associating eating chicken fries with sudden personality changing seems irrational as if 'coolness' can only be obtained by eating fries.

b. Analogy (2017)

"Life's about the little things. The little things you can hold. You can hold a Whopper. Life's about a Whopper"

Here in this example, an analogy between life and Whopper burger are established. This tweet is being playful to make someone believe Whopper is the small thing that all we need in life. This analogy can be considered faulty and not valid since it assumes two things to be similar, while in fact, they are different on each case.

In accord with SO and LM, the Situation (SI) underlying the humor tweets are also found. According to Attardo (2013), not only does humorous text, but also any text has a set of

$$
\text { - } 2016-2017 \quad 2018
$$

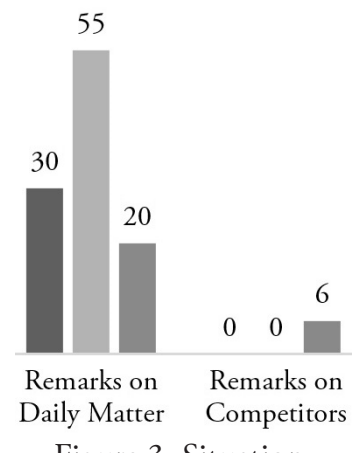

Figure 3. Situation. circumstances. Interestingly, all Burger King's humorous tweets are in the setting of either remarks on daily matters or remarks on Burger King's competitors, as can be seen in Figure 3. Another aspect is the Narrative Strategy (NS). According to Tsakona (2013), NS is how the jokes being performed or conveyed. It should be noted that Twitter has regulation to limit one tweet or 280 characters. As a result, from three kinds of narrative organization, almost all the humor from Burger King is in the form of simple narrative and less than $20 \%$ of humorous tweets come in a form of a dialogue. Even riddle jokes are nowhere to be found, as shown on Figure 4.

Figure 3 shows that remarks on daily matters are high, reaching $94 \%$ in total. This indicates that Burger King tries to engage more with their customers or followers by giving friendly remarks on everyday matters. For example,

"Whenever you feel like the whole world is against you, just remember nuggets are in your side"

This humor states Burger King's position as a supportive and reliable companion for their followers. The pronoun 'you' dictates closeness, while the content offers comfort or consolation expressed in a comical way. This is one kind of strategy that can humanize the brand since the tweet sounds personal. The situation would be different if, for example, they use the pronoun 'I' instead of 'you'.

On the other hand, the Figure 4 illustrates the percentage of narrative form used in humor tweets. Overall, more than four-fifths of humor tweets from Burger King are in the form of simple narrative. For instance, Burger King tweets,

"FACT: If you plug your phone charger into a cheeseburger, everyone will stop talking to you"

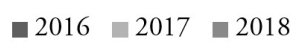

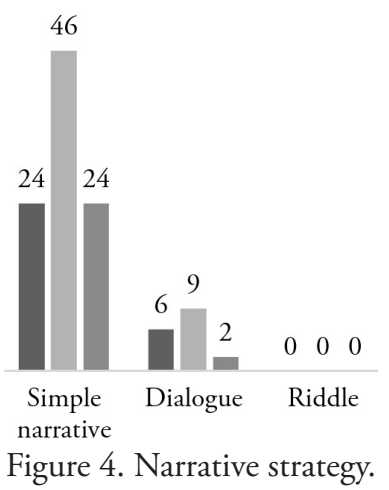


Viewed from the number of characters and types of sentence, this humor is a form of simple narrative. It does not have any questions and answers, and it just a statement. Burger King often uses this kind of organization to indirectly advertise their products. That being said, simple narrative humor may easier to make than riddle one.

In this study, it is also crucial to recognize the target of the humor. Humor can be directed at anything. The target can be more appealing if it universally appeals to a particular audience. There is some distinction in target interplay, which can be categorized into a self-oriented and other-oriented party (Beal \& Mulan, 2013). In the analysis above, there are four main targets: Burger King, customers or followers, competitors, or non-specific. There is obviously a link between the term self-oriented as Burger King and other targets as the other-oriented party.

Figure 5 compares the language used in Burger King's humor tweets in different years. Generally speaking, the data show that 46 out of 111 humors from Burger King are directed to a non-specific target. Other than that, customers become the 'butt' of the jokes reflects a high rates of $33 \%$. In the light of the above, it is suggested that Burger King is paying attention to their image by limiting offensive humor tweets to their competitors. As seen in Figure 5, the following examples are the common targets of Burger King's humor tweets:

\section{ロ $2016 \square 2017 \quad 2018$}

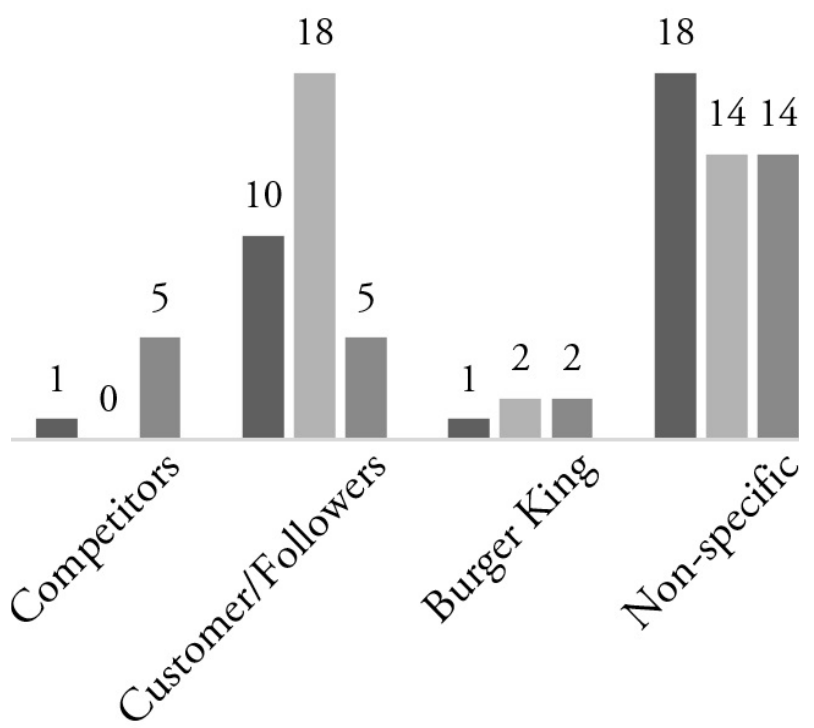

Figure 5. Target. a. Non-specific target (2016-2018)

It is interesting to note that the majority targets in 2016 and 2018 are a non-specific target.

"GIRL: can we please have a serious conversation for a sec?

* guy is reenacting movie scene with boxes of chicken fries*

GUY : this IS serious"

In this humor, there is no particular target. It is true that there are two characters in the humor, but people do not know the exact person. They just laugh at the 'girl' or person in general. In other words, the humor does not refer directly to the third-party of the communication.

b. Customer or followers (2017)

"If a potato can be fried, then you can be whatever you want"

The target of this humor is the followers or customers of Burger King's account. It shows a clear preference on targeting their followers by using the pronoun 'you'. They tease their followers or customers by associating them directly with potato for the sake of humor.

In the process of developing humor, language has an important and significant role. Cisneros, Alexanian, Begay, Goldberg (2006) propose four categories of humor language, which include puns, sarcasm, irony, and incongruity.
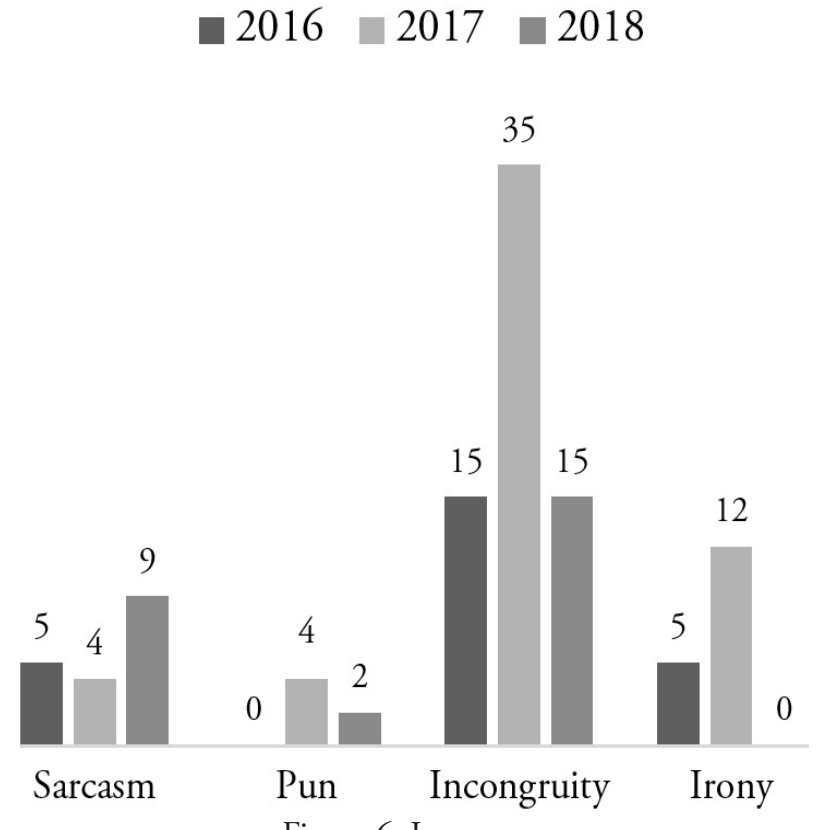

Figure 6. Language. 
Figure 6 shows the average number of language types Burger King used in three different years. According to the illustration, Burger King typically applies around 50\% incongruity humor on their tweets, followed by sarcasm with $16 \%$. The following is the example of the major technique humor language by Burger King:

- Incongruity

\section{"[Down on one knee]}

$\because]$ : Will you make me the happiest man in the world?

(110: yes yes a thousand times yes

$\because \because$ : [eat fries]"

Here in this joke, the conversation is absurd or nonsensical. The man is proposing marriage to the fries, and shortly after the fries say 'yes', the man eats the fries. Based on the theory of pragmatics, an incongruity is a form of surprise (Cisneros, et. al., 2006). On that account, the humor above contains an incongruous statement that may not be expected by the readers. No one expects the man will end up eating the fries he is about to be engaged with or to marry.

In light of the extended version of GTVH, Meta-Knowledge Resource (Meta) is the developer to understand the cues of humor (Canestrari, 2010). It involves the signal from addresses of being intentionally humorous to the addressee.

Based on the illustration in Figure 7, Burger King does not really want to indicate humorous communicative signal in their tweets. Only two of their tweets have a verbal signal which is in 2016 and 2018. This may due to the drawbacks of the medium of the humor itself. Twitter has limits. Unlike a movie or face-to-face conversation, the
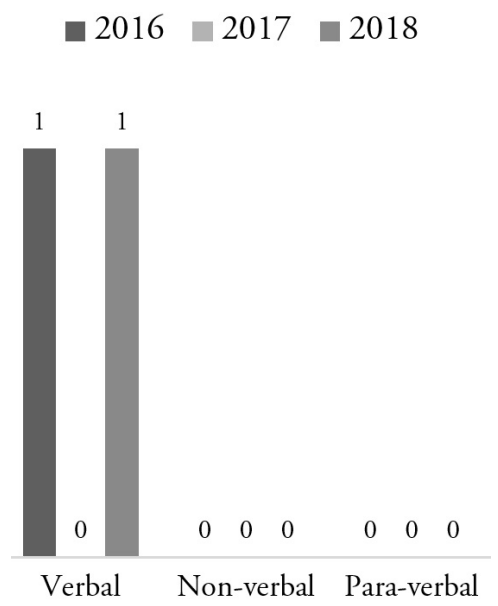

Figure 7. Meta-knowledge resources. signal from humorous tweets can only be gained from the verbal signal or explicit statement, as in the example below:

"the NEW chocolate Whopper. coming soon to your local Burger King. maybe. Jk lol."

In this humor, Burger King stated that their tweets are basically a joke. The word JK is from the saying 'Just Kidding'. This tweet happens on April's Fool Day, to trick their customers.

We note that the last $\mathrm{KR}$ is context $(\mathrm{CO})$. In using humor, sometimes the pragmatics meaning is different from one to another speaker, and it heavily depends on the culture. The example of mostly employed $\mathrm{CO}$ in Burger King tweets are seen in the Figure 8.

Figure 8 outlines the average context of Burger King's humor tweets. A total of 16 tweets in 2016 are about questioning someone's identity and the same happens in 2017, reaching 38\% of total humor tweets. Despite that, humor about identity decreases to $25 \%$ in 2018 . Consider the following example shown below:

- Identity

"Ifyou bring your friend a Whopper, you will make their day. Even if they don't know who

$$
\text { you are" }
$$

This humor suggests foods unite people. However, the underlying meaning of this tweet is that to show the identity of Americans. According to U.S Centers for Disease Control and Prevention, 79\% of Americans eat fast food at least once a week. Therefore, this humor illustrates the love American have on foods, notably fast food. In addition, this kind of humor would be considered funny to Americans, since they understand the context of it. Again, there is a metapragmatic stereotype of Americans takes an insane amount of food per day.

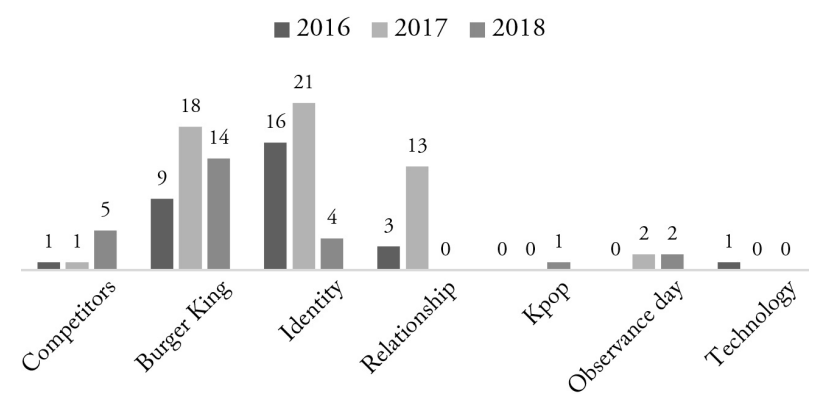

Figure 8. Context. 


\section{Text Functional Analysis}

The overall agenda of Burger King on using humor as a strategy in social media is to manage business engagement, shape their image, and increase sales. It suggests that Burger King's humorous tweets mostly have different function each year. As such, successful brand engagement in social media may rely to a greater extent on humorous tweets, as shown on Figure 9.

On the text functional analysis, $43 \%$ humor tweets in 2016 are more on contact function (Figure 9). On the other hand, Burger King changes their intention of posting humorous tweets into appellative by $60 \%$. In 2018 , it is reported that 11 out of 26 humor tweets have an informative function. Hence, it can be concluded that among eight KRs and text functional, their intention of using humor often changes throughout time. For example:

a. Contact (2016)

"[Morning drive-thru]

$B K \quad$ : Can I take your order?

GUY : Ummmmmm.

$B K$ :

$G U Y$ :

$B K$ :

GUY: I can't think.

$B K$ : Coffee. Got it."

Given the fact that Burger King creates an image of always understanding what their customer want, this humor has a function to indicate that Burger King wishes to build an intimate and personal relationship with the — $2016 \square 2017 \square 2018$

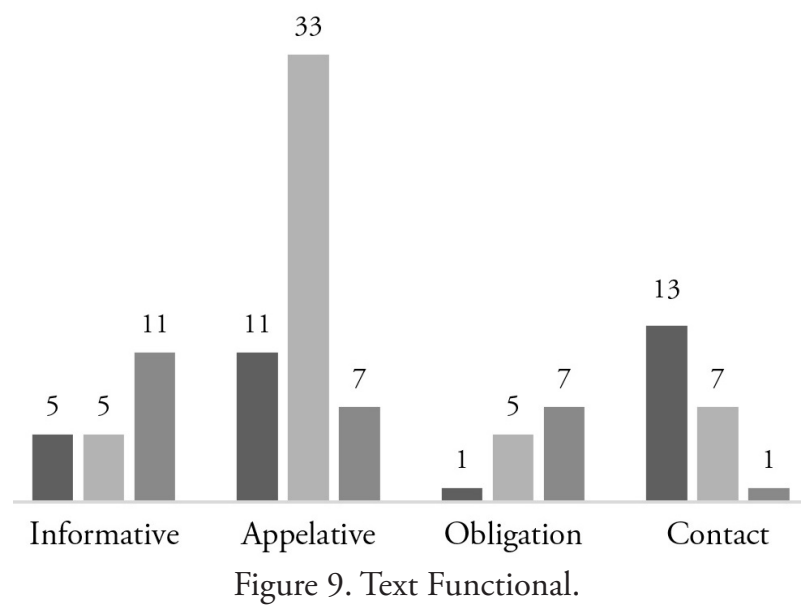

customer. This is similar to what best friend do to each other, which is understanding. In the meantime, the persona of Burger King becomes more 'humanized' in a way.

b. Appellative function (2017)

"No, it's not weird if you carry a photo of an onion ring in your wallet."

In this tweets, Burger King is giving an advice to their customers. However, the intention of this humor is to make the customers perform a specific activity. Burger King asks them to love onion ring more than their loved one. As a consequence, if more people agree on their statement, the sales of onion rings will increase significantly.

c. Informative function (2018)

"it can't be the end of iced coffee season if there is no "iced coffee season"

From this humorous tweet, it seems that Burger King is just playing around with one's logic. As such, Burger King emphasizes the factor information that everyone may already know before. After all, the purpose of this humor tweet is clear and direct, which is giving information that there is no iced coffee season and they always sell iced coffee.

\section{Conclusion}

This study aims to find the construction of Burger King's humor tweets from each year and its pragmatic function. Through the comparison textual analysis of 111 humor tweets on Burger King's Twitter account, it is confirmed that Burger King has different strategies of using humor each year. Specifically, after applying General Theory of Verbal Humor (GTVH) it is found that Burger King uses different kinds of humor. The findings reveal a number of significant dissimilarities on the use of Script Opposition (SO), Language Mechanism (LM), Target (TA), and Context (CO). As the script opposition has the highest parameters in knowledge resources, it can be concluded that Burger King more frequently offers actual or non-actual humor in 2016, normal or abnormal humor in 2017, and lastly possible or impossible humor in 2018. Using Brinker (2005) Text Functional Analysis, this study 
also finds that the Burger King's humor tweets are mainly used as an indirect advertisement, such as humanizing the brand, asking the audience to do something, and promote the product.

Together, it shows that the humor clearly affects Burger King's brand image in an indirect way. The humor tweets from Burger King is a good illustration in terms of projecting business engagement in social media. This study provides value to the development of humor and linguistics studies, as well as bring valuable insights to brand alike, due to the relevance outcomes that can be used for social media strategy. One limitation of the present study is the impression metrics are not calculated. The potential impression of the humor tweets gives an idea how many times the tweets shown up in people's timeline. In other words, future research should examine the relationship between humor and the metric of impression. If it is addressed, the future study on humor tweets has the potential to produce more in-depth results.

\section{References}

Adegoju, A., \& Oyebode, O. (2015). Humour as discursive practice in Nigeria's 2015 presidential election online campaign discourse. In Discourse Studies. DOI:10.1177/ 1461445615602378

Alaman, A. P., \& Rueda A. M. (2015). Humor and advertising in twitter. In Metapragmatic of Humor. Retrieved from https://books.google. co.id/books? isbn=9027266379

Arhoj, J. (2011). A linguistic study on the communication of the corporate identity based on corporate websites in Germany and Denmark. In Thesis (Unpublished).

Attardo, S., \& Raskin, V. (1991). Script theory revis(it)ed: Joke similarity and joke representation model. In Humor: International Journal of Humor Research, 293 -347. DOI : https:// doi.org/10.1515/humr.1991.4.3-4.293

Attardo, S. (2013). The Routledge Handbook of Language and Humor. New York: Routlegde.

Attardo, S., \& Hampelmann, C. F. (2002). Script oppositions and logical mechanism: modeling incongruities and their resolutions. In Humor:
International Journal of Humor Research. DOI: https://doi.org/10.1515/humr.2002.004

Burger King statistics and facts. (n.d.). In Statista. Retrieved from https://www.statista.com/ topics/1460/burger-king/

Burger King (@Burgerking). Retrieved from Twitter.com

Beal, C., \& Mullan, K. (2017). The pragmatics of conversational humor in social visits: French and Australian English. In Language and Communication Journal. DOI: https:// remote-lib.ui.ac.id:2067/10.1016/j. langcom.2016.09.004

Canestrari, C. (2010). Meta-communicative signals and humorous verbal interchanges: a case study. In Humor: International Journal of Humor Research, 4: 293-347. DOI: https:// doi.org/10.1515/humr.2010.015

Canestrarti, C., \& Bianchi, I. (2013). From perception of contraries to humorous incongruities. In Developments in Linguistic Theory, Marta Dynel (ed), 3-4. Amsterdam: John Benjamins.

Cisneros, R. E., Alexanian, J., Begay, J., \& Goldberg, M. (2006). The language of humor: Navajo. In Santa Barbara Papers in Linguistics. Retrieved from http://www.linguistics.ucsb. edu/sites/secure.lsit.ucsb.edu.ling.d7/files/ sitefiles/research/papers/18/Cisneros.et_. al_vol18.pdf

Davis, J. L., Love, T. P., \& Killen, G. (2018). Seriously funny: The political work of humor on social media. In Journal of New Media \& Society. DOI: 10.1177/1461444818762602 Exaggeration. (n.d.). In Oxford Living Dictionaries. Retrieved from https://en.oxforddictionaries. com/definition/exaggeration

Farías, D. I. H. (2017). Irony and Sarcasm Detection in Twitter: The Role of Affective Content. In Dissertation (Unpublished). Retrieved from http://users.dsic.upv.es/ - prosso/resources/ IrazuHernandezPhD.pdf

Fryer, C. D., Hughes, J. P., Herrick, K. A., \& Ahluwalia, N. (2018). Fast food consumption among adults in the United States, 20132016. In NCHS Data Brief. Retrieved from cdc.gov 
Hempelmann, C. F., \& Ruch, W. (2005). 3 WD meets GTVH: Breaking the ground for interdisciplinary humor reseacrh. In Journal of Humor Research

Hoicka, E. (2014). The pragmatic development of humor. DOI: 10.13140/2.1.2207.5524

Lalancette, M., \& Raynauld, V. (2017). The power of political image: Justin Trudeau, instagram, and celebrity politics. In Journal of American Behavioral Scientist. DOI:10.1177/0002764217744838

Martin, R. A., Puhlik-Doris, P., Larsen, G., Gray, J., \& Wier, K. (2003). Individual differences in uses of humor and their relation to psychological well-being: Development of the humor style questionnare. In Journal of Research in Personality. DOI: https://doi. org/10.1016/S0092-6566(02)00534-2

Masaeli, B., \& Shahreza, H. M. A. (2016). A linguistic analysis of Persian online jokes in light of General Theory of Verbal Humor. 230-239. Retrieved from http://www.jallr. com/index.php/JALLR/article/view/458

Paolillo, J. (1999). The virtual speech community: Social network and language variation on
IRC. In Journal of Computer-Mediated Communication. DOI: https://doi.org/10.1111/ j.1083-6101.1999.tb00109.x

Simon, S. (2008). The pragmatic structure of written advertisement. In Professional Communciation and Translation Studies. DOI: https://doi. org/10.1016/j.sbspro.2015.06.033

Tsakona, V. (2013). Okras and the metapragmatic stereotypes of humor: towards an expansion of the GTVH. In Developments in Linguistic Theory, Marta Dynel (ed), 25-.43. Amsterdam: John Benjamins.

Tsakona, V., \& Chovanec, J. (2018). The dynamic of interactional humor: creating and negotiating humor in everyday encounters. Amsterdam: John Benjamins.

Raskin, V. (1985). Semantic mechanisms of humor. Dordrecht, The Netherlands: D. Reidel.

Yliopisto, H. (2016). Twitter discourse: Hashtags as pragmatic markers. Retrieved from https://helda.helsinki.fi/bitstream/handle/ 10138/168144/Laukkanen_Essi_ProGradu_ 2016.pdf?sequence $=2$

Ziv, Avner. (1984). Personality and Sense of Humor. New York: Springer. 